\title{
ДОСВІД ЖИТОМИРСЬКОГО ІНСТИТУТУ МЕДСЕСТРИНСТВА В МІЖНАРОДНОМУ СПІВРОБІТНИЦТВІ
}

\author{
В. Й. Шатило, В. А. Копетчук, С. В. Гордійчук, О. В. Горай, І. Р. Махновська
}

Житомирський інститут медсестринства

\section{THE EXPERIENCE OF ZHYTOMYR INSTITUTUTE OF NURSING IN THE INTERNATIONAL COLLABORATION}

\author{
V.Y. Shatylo, V.A. Kopetchuk, S. V. Hordiychuk, O. V. Horay, I. R. Makhnovska \\ Zhytomyr Institute of Nursing
}

\begin{abstract}
У статті розглянуто досвід міжнародного співробітництва Житомирського інституту медсестринства. Розкриті основні напрямки та загальні підходи до реалізації концепції розвитку міжнародного співробітництва, висвітлені стратегії та кроки співробітництва у сфері професійної підготовки медичних працівників.
\end{abstract}

In the article the experience of the international collaboration of Zhytomyr Institute of Nursing was considered. The main directions and general approaches for the realization of conception of development the international collaboration were defined; also the main strategies and the steps of collaboration in the sphere of professional training of medical workers were pointed out.

Вступ. Національна доктрина розвитку освіти України у XXI столітті проголошує: “Освіта - стратегічна основа розвитку особистості, суспільства, нації й держави, запорука майбутнього, найбільш масштабна і людиноємна сфера суспільства, його політичної, соціально-економічної, культурної й наукової організації. Вона $\epsilon$ засобом відтворення й нарощування інтелектуального, духовного потенціалу народу, виховання патріота і громадянина, дієвим чинником модернізації суспільства, зміцнення авторитету держави на міжнародній арені” [1].

Активна міжнародна консолідація у сфері освіти та науки спрямована на приєднання України до процесу створення єдиного європейського наукового й освітнього простору - зони “Свропейської вищої освіти”, у рамках якої освіта набуває прозорості, конкурентоспроможності та стає порівнюваною. Європа визнає освіту та дослідження основою для побудови науково організованого суспільства, тому здатність навчальних закладів максимально використовувати можливості, які виникають у сфері міжнародного співробітництва, виявляється вирішальною для їхнього процвітання [2].

Проблеми міжнародної діяльності вищих навчальних закладів та вироблення підходів до формування концепції розвитку міжнародного співробітництва розглядають такі українські автори, як В. Г. Кремень, М. Ф. Степко, Я. Я. Болюбаш, О. В. Співаковський,
В. З. Грищак. На актуальності питань співробітництва університетів із зарубіжними організаціями, фондами, грантодавцями наголошують О. І. Шнирков, I. О. Мінгазутдінов, С. А. Шмельова, Т. Ю. Подобєдова. Незважаючи на те, що за останнє десятиліття відбулися значні зміни у вищій школі, які спричинили реформування системи вищої освіти України відповідно до міжнародних стандартів та норм, важливим сьогодні залишається розкриття тих можливостей, які дозволяють сучасному навчальному закладу інтегруватись до світового освітнього простору.

Основна частина. Сьогодні Житомирський інститут медсестринства - вищий навчальний заклад, який вперше в Україні запровадив сучасні освітні стандарти у підготовці медичних кадрів - ступеневу медсестринську освіту. Підготовку медичних фахівців для потреб практичної охорони здоров'я області та держави проводиться за 7 акредитованими спеціальностями: “Лікувальна справа" (фельдшер), “Сестринська справа” (медична сестра), “Стоматологія” (зубний гігієніст), “Акушерська справа” (акушерка), “Стоматологія ортопедична” (зубний технік), “Сестринська справа” (медична сестра-бакалавр), “Сестринська справа" (медична сестра-магістр).

За час свого існування навчальний заклад підготував близько 30 тисяч спеціалістів середньої ланки системи охорони здоров'я та понад 300 медсестер-бакалаврів. На кафедрі післядипломної освіти “Загаль-

(c) В. Й. Шатило, В. А. Копетчук, С. В. Гордійчук та ін. 
на практика - сімейна медицина" підготовлено близько 400 сімейних лікарів. У відділенні післядипломної освіти підвищили свою кваліфікацію та пройшли курси спеціалізації понад 14 тисяч молодших медичних спеціалістів. У 2008 році, згідно з Програмою реформування медсестринства в Україні на 2005-2010 pр., в інституті запроваджено ступеневу медсестринську освіту та здійснено прийом на навчання в магістратуру за спеціальністю “Сестринська справа”. У червні 2010 року відбулись урочистості з нагоди першого випуску 19 магістрів, які отримали дипломи 3 вищою медсестринською освітою та поповнили лави представників медичної еліти держави.

У навчальному закладі створено всі умови для здійснення навчання, а також для творчої та наукової праці. Навчально-виховний процес здійснюють 241 викладач, 3 науковим ступенем - 9 докторів наук, 34 кандидати наук, 5 із них мають вчене звання профеcopa, 12 - доцента; 67 \% викладачів мають вищу та першу категорії, серед них 38 викладачів-методистів.

Концепція освітньої діяльності інституту грунтується на засадах Національної доктрини розвитку освіти, Закону України “Про освіту”, Закону України “Про вищу освіту”, інших чинних законодавчих актів, які регламентують діяльність вищих навчальних закладів. Вона передбачає поступове і неухильне покращення рівня підготовки спеціалістів з ліцензованих напрямів і спеціальностей за рахунок покращення матеріально-технічної бази, кадрового забезпечення навчально-виховного процесу, удосконалення форм $\mathrm{i}$ методів навчальної роботи.

Вся освітня система інституту безперервно модернізується з урахуванням принципів гуманізації, демократизації, науковості, безперервності освіти, практичності, адаптивності.

Матеріально-технічна база інституту відповідає вимогам державних та галузевих стандартів підготовки спеціалістів. Її розширення (створення науково-методичної лабораторії, нових кабінетів інформаційних технологій тощо) дало можливість створити умови для успішного впровадження інноваційних технологій у навчальний процес. Значною подією у житті навчального закладу стало відкриття нового Конгрес-центру на 650 місць, що дало можливість проводити заходи державного та обласного рівнів.

Одним із актуальних напрямків ефективного розвитку Житомирського інституту медсестринства $є$ міжнародне співробітництво, головною метою якого $\epsilon$ формування позитивного міжнародного іміджу інституту, підтримка та розвиток зарубіжних відносин в освітньо-наукових, соціальних, культурних сфе- рах. Контакти 3 вищими навчальними закладами інших країн дозволяють значно підвищити кваліфікацію співробітників шляхом проведення спільних наукових досліджень, організації стажувань викладацького та студентського складу, покращити або розробити нові програми, організувати обмін викладачами та студентами.

Основні напрямки роботи з міжнародного співробітництва Житомирського інституту медсестринства викладено нижче.

Підтримка якісного рівня навчання та дослідницької діяльності з використанням міжнародного співробітництва і сприяння мобільності науковців, викладачів та студентів.

Встановлення міжнародного співробітництва в галузі досліджень та пошук міжнародних контактів, необхідних для наукової, науково-практичної та навчально-методичної роботи інституту. Для забезпечення цього завдання ведеться співпрацяз ТОВ “Освітньо-культурні обміни”, Київським молодіжним центром праці, 3 американською компанією "Professional Resources International", проводиться робота за програмами Work \& Study, Work \& Travel.

Розвиток прямих контактів з провідними університетами, благодійними організаціями та клініками США, Канади, Італії, Польщі, Німеччини, Хорватії, Росіі, Грузіі.

Так, під девізом “Захисти життя” відбулась конференція в Житомирському інституті медсестринства за участю гостя зі Сполучених Штатів Томаса Маккена, президента благодійної організації “ Гільдія Святої Жанни Берети Молли”. Організація, яку він очолює, популяризує моральну етику в медичній практиці, цінність людського життя, здорову традиційну сім'ю.

Метою Гільдії є об'єднання і підтримка лікарів та медичних працівників, які прагнуть вирішувати питання, що хвилюють суспільство, а особливо ті, які пов’язані з медичною практикою.

Великий інтерес викликала зустріч з доктором медичних наук Антуаном Лісицем (Хорватія, клініка “Про Віта"). Під час зустрічі були розглянуті питання біоетики.

Поширення участі науково-педагогічних працівників у міжнародних наукових форумах. У рамках цього завдання співробітники інституту Н. П. Леонченко, С. В. Гордійчук, І. М. Круковська пройшли курси підготовки інструкторів-викладачів за програмою “Фінансування та управління в сфері охорони здоров’я України”, що проводились за сприяння Свропейського Союзу.

У рамках україно-американського проекту підготовки медичних спеціалістів спільно з медичним ко- 
леджем університету Снерсі (штат Джорджія, Атланта, США) за програмою, розробленою провідними фахівцями США, з 2005 року в інституті запроваджено пілотний проект підготовки медичних сестер на рівні світових стандартів.

На виконання п. 18 Загальнодержавної цільової програми забезпечення профілактики ВІЛ-інфекцій, лікування, догляду та підтримки ВІЛ-інфікованих і хворих на СНІД на 2009 - 2013 роки, затвердженої Постановою Кабінету Міністрів України № 264 від 04.03.2009 р.та з метою підготовки фахівців на дота післядипломному етапах з питань ВІЛ-інфекцій під егідою і при сприянні Дитячого фонду ООН (ЮНІСЕФ) створено на базі Житомирського інституту медсестринства та Обласного центру профілактики та боротьби зі СНІДом Всеукраїнський тренінговий центр з питань профілактики передачі ВІЛ від матері до дитини. В тренінговому центрі проходять навчання 380 викладачів вищих медичних навчальних закладів України.

Проведення спеціальних наукових розробок і виконання наукових робіт з грандами, розробленими фондами іноземних держав.

Викладачами кафедри “Сестринська справа” та студентами-магістрами були розроблені проекти, 3 якими вони взяли участь у програмі літньої школи “Права людини та медицина” (Польща).

Помічник ректора $з$ міжнародного співробітництва Горай Ольга Віцентіївна пройшла курс навчання в Вебб Інституті лідерства, маркетингу та демократії при Раскін коледжі в Оксфорді (Великобританія) та отримала акредитацію.

Співробітники інституту мали можливість обмінятись досвідом з підготовки фахівців на Young Europe Forum (Краків, Республіка Польща) та були учасниками дистанційного навчання, що проводилося в рамках проекту “Центр польсько-української співпраці в Кракові”. Навчання охоплювало такі питання: якість в управлінні, європейська інтеграція, громадські організації тощо.

Особлива увага в розвитку міжнародного співробітництва приділяється науковій діяльності. В цьому напрямку запроваджено нижчеподане.

Обмін запрошеннями для участі у науково-практичних конференціях та семінарах, у тому числі студентських, підготовка і видання спільних наукових праць. Для виконання цього завдання проводились наукові форуми за участю науковців Свропи та США. Співробітники інституту мали можливість пройти курси з надання невідкладної допомоги та реанімації за програмою підготовки до Євро - 2012 в Кракові (Республіка Польща).
Брали участь у Міжнародній науково-практичній конференції “III Жезовські читання 3 медсестринства. Громадське здоров'я. Медсестринство ХХІ сторіччя" (м. Жезов, Республіка Польща). Цікавим виявився досвід Республіки Польща 3 підготовки магістрів зі спеціальності “Акушерська справа” та впровадження медсестринства як наукової спеціальності.

Проведення двосторонніх наукових стажувань викладачів і студентів.

У грудні 2009 р. представники інституту медсестринства увійшли в склад делегації до Італійської Республіки. Під час перебування були проведені зустрічі з керівництвом Обласної адміністрації Лігурії, з керівництвом Національного університету міста Генуї, 3 представниками Національної федерації медсестер Італії. Під час зустрічей погоджено питання обмінудосвідом і участь італійських викладачів в навчальному процесі інституту медсестринства.

Співробітники інституту в липні 2010 року в рамках програми україно-французького співробітництва у сфері охорони здоров'я та фармації мали можливість ознайомитись $з$ організацією охорони здоров'я Франції, організацією навчання на медичних факультетах, історичною спадщиною медицини Франції. Під час візиту співробітники відвідали відділення спеціалізованої педіатрії Дитячого клінічного центру Роберта Добре, медичного центру та музею Інституту Пастера, відділення анестезіології та реанімації Клінічного центру Кошен, Інститут Париж V- Рене Декарт, лабораторію Eurofins Pharma Control, відділення радіології шпиталю Hotel Dieu, відділення ортопедичної і травматологічної хірургії шпитального центру Орсей.

11-14 січня 2011 р. делегація Житомирського інституту медсестринства побувала з робочим візитом у Тбілісі, де відбулася зустріч $з$ представниками університету Еморі (США), представниками навчального центру для медичних сестер (Грузія).

Змістовні презентації, дискусії з представниками американської та грузинської делегації, ознайомлення 3 організацією практичної підготовки медсестер Грузії окреслили пріоритети співпраці у різних галузях наукової та практичної медицини.

Запорукою та платформою подальшого спільного поступу є досягнута домовленість про подальшу співпрацю. Візит делегації Житомирського інституту медсестринства відкривав нові перспективи у розвитку міжнародного співробітництва і підвищення рівня підготовки медсестринських кадрів до європейських і світових стандартів.

Участь у підготовці й виконанні спільних наукових проектів, у тому числі в рамках міждержавних про- 
грам та міжнародних грандів. Науково-педагогічні співробітники інституту беруть участь у Міжнародному проекті MATRA, з Mohawk Collegeof Applied Arts and Technology (Канада).

Заклад підтримує тісні міжнародні зв'язки, здійснює обмін інформацією, навчальними програмами та навчальною літературою з медичними навчальними закладами Канади, США.

Для виконання програми підготовки до Євро-2012 співробітники та студенти інституту проходять курси вивчення та удосконалення англійської мови за програмою “Золотий стандарт”.

Планується співпраця в галузі культури та спорту: організація заходів 3 метою кращого ознайомлення українських громадян з культурою інших держав; обмін запрошеннями для участі у фестивалях, конкурсах та інших культурно-масових заходах, що проводяться навчальними закладами; проведення спільних змагань між спортсменами навчальних закладів.

У галузі менеджменту заплановані взаємні візити представників управління та адміністрації навчальних закладів для консультацій, погодження реалізації

\section{Література}

1. Національна доктрина розвитку освіти України у 21 столітті.-К. : Освіта, 2001.-С. 2-3.

2. Высшее образование в XXI в. : подходы и практические меры (ЮНЕСКО, Париж, 5-9 октября, 1998 ) // умов співробітництва та обміну досвідом з питань управління вищим навчальним закладом.

Висновок. Найважливіший фактор усіх досягнень та здобутків навчального закладу - творчий високопрофесійний педагогічний колектив. Саме завдяки його самовідданій праці сьогодні формується високий імідж інституту в державі та за кордоном.

Таким чином, складання концепції розвитку міжнародної діяльності та участь у спільних освітніх проектах мають стратегічне, концептуальне значення для Житомирського інституту медсестринства. Очевидною $є$ необхідність подальших досліджень 3 міжнародного вектора співробітництва, широкого розповсюдження результатів аналізу накопиченого досвіду під час організації та проведення семінарів, тренінгів, конференцій та підготовки спеціальних методичних посібників з метою активізації міжнародної діяльності. Це надасть змогу не лише отримати доступ до новітніх технологій і методик у навчальній сфері, підвищити свою конкурентоспроможність, але й якнайшвидше стати повноправними членами світового науково-освітнього товариства.

AlmaMater--K., 1998.-№ 11.-C. 3-9.

3. Болонський процес у фактах і документах / [упорядники М. Ф.Степко, Я. Я. Болюбаш, В.Д. Шинкарук та ін.]. Київ - Тернопіль : Вид-во ТДПУ, 2003. - 52 с. 